\title{
Distribution and prevalence of Anguillicola crassus (Nematoda) in eels Anguilla anguilla of the rivers Rhine and Naab, Germany
}

\author{
Jürgen Würtz ${ }^{1, *}$, Klaus Knopf ${ }^{2}$, Horst Taraschewski ${ }^{2}$ \\ ${ }^{1}$ Institut für Zoologie und Limnologie, Universität Innsbruck, Technikerstraße 25, A-6020 Innsbruck, Austria \\ ${ }^{2}$ Zoologisches Institut/Ökologie, Universität Karlsruhe, Kaiserstraße 12, D-76128 Karlsruhe, Germany
}

\begin{abstract}
Over a period of 2 yr eels were collected at several sites along the river Rhine as well as from adjacent waters and examined for Anguillicola crassus in the swimbladder. Additionally eels were collected once from a site on the river $\mathrm{Naab}$ (Danube system). All eels were searched for both juvenile and adult stages of $A$. crassus, revealing prevalences of $80 \%$ in eels from the river Rhine and $39 \%$ in eels from the river Naab. The mean intensities were 5.6 and 7.7, respectively. With respect to the prevalence and mean intensity of infection, no significant differences were observed between the different sampling sites in the Rhine system. Neither the prevalence nor the intensity showed significant seasonal patterns. Further, no correlation between the condition factor of the eels and intensity of infection with $A$. crassus could be found. Of all eels examined, $28 \%$ showed pathological alterations of the swimbladder.
\end{abstract}

KEY WORDS: Anguillicola crassus Anguilla anguilla - Swimbladder · Distribution Prevalence

\section{INTRODUCTION}

The genus Anguillicola, Yamaguti 1935, is comprised of 5 species (Moravec \& Taraschewski 1988) All species inhabit the swimbladder of eels (genus Anguilla) in various regions of the world. Four species show a relatively limited distribution whereas Anguillicola crassus, which originated in East Asia, rapidly spread all over Europe after it was introduced in the early 1980s (Neumann 1985, Canestri-Trotti 1987, Taraschewski et al. 1987, Dupont \& Petter 1988, Koie 1988, Moravec \& Taraschewski 1988, Belpaire et al. 1989, Dekker \& Van Willigen 1989, Koops \& Hartmann 1989, Fontaine et al. 1990, Kennedy \& Fitch 1990, Koie 1991, Möller et al. 1991, Székely et al. 1991, Höglund et al. 1992, Moravec 1992). It also occurs in some African countries and the Mediterranean Sea (Moravec 1992, Benajiba et al. 1994, El Hilali et al. 1996). It is now also found in Anguilla rostrata in the USA (Johnson et al. 1995, Fries et al. 1996). This rapid spread shortly after the introduction of $A$. crassus was assisted

•E-mail juergen.wuertz@uibk.ac.at by human interference (Belpaire et al. 1989, Kennedy \& Fitch 1990) and the excellent colonization ability of A. crassus (Kennedy \& Fitch 1990). The life cycle of $A$. crassus involves mainly cyclopid copepods as intermediate hosts (Egusa 1979. De Charleroy et al. 1990, Kennedy \& Fitch 1990, Bonneau et al. 1991, Thomas 1993. Würtz et al. 1996) as well as other crustaceans (Petter et al. 1990, Bonneau et al. 1991, Thomas 1993, Moravec \& Konecny 1994). About 30 fish species are known to serve as paratenic hosts, which has further facilitated the spread of $A$. crassus (De Charleroy et al. 1990, Haenen \& Van Banning 1990, 1991, Thomas \& Ollevier 1992a, Moravec \& Konecny 1994, Pazooki \& Székely 1994, Reimer et al. 1994, Székely 1994, 1995, 1996, Székely et al. 1996). Additionally, at least one species of aquatic snails can act as paratenic host for $A$. crassus (Moravec 1996). This low host specificity certainly accelerated the spread of $A$. crassus once it reached a non-parasitized water system.

Although many reports of the occurrence of Anguillicola crassus have been published (Canestri-Trotti 1987, Taraschewski et al. 1987, Koie 1988, Belpaire et al. 1989, Dekker \& Van Willigen 1989, Koops \& Hart- 
mann 1989, Fontaine et al. 1990, Kennedy \& Fitch 1990, Möller et al. 1991, Höglund et al. 1992, Moravec 1992, Spangenberg \& Reinhold 1992, Pilcher \& Moore 1993, Barus 1995, Molnár \& Székely 1995, Barus et al. 1996), it remains unclear whether the prevalence and intensity of infection with $A$. crassus in European eel populations is still increasing. Data from The Netherlands show a decrease in prevalence and intensity (Haenen et al. 1994), and Ashworth (1994) states that intensities of infection reach a stable level after some time. On the river Rhine at Karlsruhe a study of eels was set up to examine whether a similar trend in the decrease of prevalence of $A$. crassus could be observed, if prevalence is still increasing, or if the parasite ponulation had already reached a stable level. Additionally, eels from the river Naab were examined for $A$. crassus. The river Naab belongs to the Danube system which is naturally free of eels (Bless et al. 1994). Eel populations in the Naab are therefore due to stocking by man.

\section{MATERIAL AND METHODS}

A total of 355 eels Anguilla anguilla were collected from different sample sites in the Rhine system near Karlsruhe between June 1994 and November 1995. In the river Naab (N), 38 eels were caught in October 1994. The eels were caught by electric fishing, except for a sample from the Rhine backwater 'Rußheimer Altrhein' (RA) which was taken once from fyke nets.

Table 1. Dates of fishing and sample sites. (Site abbreviations are explained in 'Material and methods')

\begin{tabular}{|llr|}
\hline Date & Sample site & $\mathrm{n}$ \\
\hline 1994 & & \\
$28 \mathrm{Jun}$ & $\mathrm{S}$ & 7 \\
$22 \mathrm{Jun}$ & $\mathrm{RA}$ & 22 \\
$23 \mathrm{Aug}$ & $\mathrm{HF}$ & 2 \\
$23 \mathrm{Aug}$ & $\mathrm{S}$ & 10 \\
$26 \mathrm{Sep}$ & $\mathrm{HR}$ & 22 \\
$28 \mathrm{Sep}$ & $\mathrm{F}$ & 23 \\
25 Oct & $\mathrm{N}$ & 38 \\
8 Nov & $\mathrm{HR}$ & 23 \\
8 Nov & $\mathrm{HF}$ & 20 \\
1995 & & \\
$14 \mathrm{Mar}$ & $\mathrm{F}$ & 25 \\
$4 \mathrm{May}$ & $\mathrm{S}$ & 11 \\
4 May & $\mathrm{HF}$ & 26 \\
8 Aug & $\mathrm{S}$ & 16 \\
8 Aug & $\mathrm{HR}$ & 23 \\
8 Aug & $\mathrm{HF}$ & 24 \\
24 Oct & $\mathrm{F}$ & 30 \\
7 Nov & $\mathrm{S}$ & 17 \\
7 Nov & $\mathrm{HR}$ & 24 \\
7 Nov & $\mathrm{HF}$ & 20 \\
& & \\
\hline
\end{tabular}

On the river Rhine 4 regular sample sites, differing in water velocity and zooplankton density, were set up and monitored uver the whole period (Table 1). These were situated at the following locations: (1) the 'Hauptrhein' (the main course of the Rhine) in front of the 'Strandbad Rappenwörth': highest current speed, lowest zooplankton content (HR); (2) the backwater 'Salmengrund': medium current speed, medium zooplankton content (S); (3) basin 'Hafenbecken III' at the Rhine harbour of Karlsruhe: no current, medium zooplankton content (HF); (4) the gravel pit lake 'Fermasee' near Neuburgweiher: no current, highest zooplankton content (F).

Live eels were transported to the laboratory, and their weight $(\mathrm{g})$ and length $(\mathrm{cm})$ was recorded. Afterwards they were killed by decapitation, the abdomen was opened and the swimbladder removed. Adult/ preadult worms were removed from the swimbladder lumen and sex was determined. The swimbladder wall was then searched for larvae by using 2 perspex plates and a stereo binocular microscope (Stemi 2000, Zeiss, Germany) with magnifications ranging from $16 \times$ to $40 \times$. Alterations of the swimbladder wall were recorded and divided into 4 damage classes (similar to Hartmann 1994): dc 0 (damage class 0) swimbladders without tissue alterations, the swimbladder wall is thin and transparent; dc 1 (damage class 1) the swimbladder wall is slightly thickened and cloudy; dc 2 (damage class 2) swimbladders with thickened, cloudy walls and dilated blood vessels; dc 3 (damage class 3) swimbladders with heavily thickened, opaque walls, dilated blood vessels and restricted lumen.

Weight and length data for all eels were used to calculate the condition factor (Bagenal \& Tesch 1978). For statistical analysis the $H$-test (Kruskall-Wallis test) was employed. Significance was accepted for $p \leq 0.0 .5$. To analyse correlations between different parameters the Spearman correlation coefficient was used (Lienert 1986, Sachs 1992). The statistical tests were performed with SYSTAT 5.0 running on a Macintosh computer.

\section{RESULTS}

The measured lengths, weights and condition factors of the investigated eels are summarised in Table 2. In regard to the condition factors no significant differences were found between eels from the rivers Rhine and Naab.

The prevalences pooled over all sampling dates and mean intensities of all Anguillicola crassus stages in the eels from the 2 river systems are presented in Fig. 1. The data for the different developmental stages are summarised in Table 3 . The eels from the 2 different river systems, Rhine and Naab, showed significant 
Table 2. Anguilla anguilla. Length, weight and condition factor of all eels examined

\begin{tabular}{|lcccccc|}
\hline & & Rhine $(\mathrm{n}=355)$ & & \multicolumn{2}{c|}{ Naab $(\mathrm{n}=38)$} \\
Length $(\mathrm{cm})$ & Weight $(\mathrm{g})$ & c-factor & Length $(\mathrm{cm})$ & Weight $(\mathrm{g})$ & c-factor \\
\hline Min. & 16 & 8 & 0.08 & 38 & 58 & 0.1 \\
Max. & 79 & 958 & 0.26 & 75 & 684 & 0.19 \\
$\bar{x} \pm \mathrm{SD}$ & $48 \pm 10.5$ & $200 \pm 136$ & $0.153 \pm 0.02$ & $52 \pm 9.5$ & $239 \pm 151$ & $0.145 \pm 0.02$ \\
\hline
\end{tabular}

differences ( $\mathrm{p} \leq 0.001)$ in both prevalences and mean intensities. The prevalence in eels from the Rhine $(80 \%)$ was more than twice as high as in eels from the Naab (39\%) although the mean intensity was higher in the Naab. No correlation could be found between intensity of infection with $A$. crassus and weight or length of infected eels. Furthermore, no correlation between intensity and condition factor could be observed.

The eels from the different sample sites at the Rhine system showed no significant differences, either in prevalence or in intensity of infection. Although slight differences in prevalence and intensities between the different sampling dates could be found, these differences were not statistically significant and no seasonal patterns in prevalence or intensity were found, either with adult or with larval stages. The prevalences and intensities remained stable throughout the $2 \mathrm{yr}$ of observation, and no increasing or decreasing trend could be observed.

Out of the 92 examined eels from site HR, 70 were infected with 6.3 Anguillicola crassus on average. The lowest prevalence (64\%) was found in autumn 1994, the highest in autumn 1995 (92\%). The highest prevalence at site $\mathrm{S}$ was found in summer 1994 (100\%), the lowest in spring 1995 (64\%); 48 out of 61 eels from this site were found to be infected with $5.4 \mathrm{~A}$. crassus on average. At site HF, 74 out of 92 eels examined

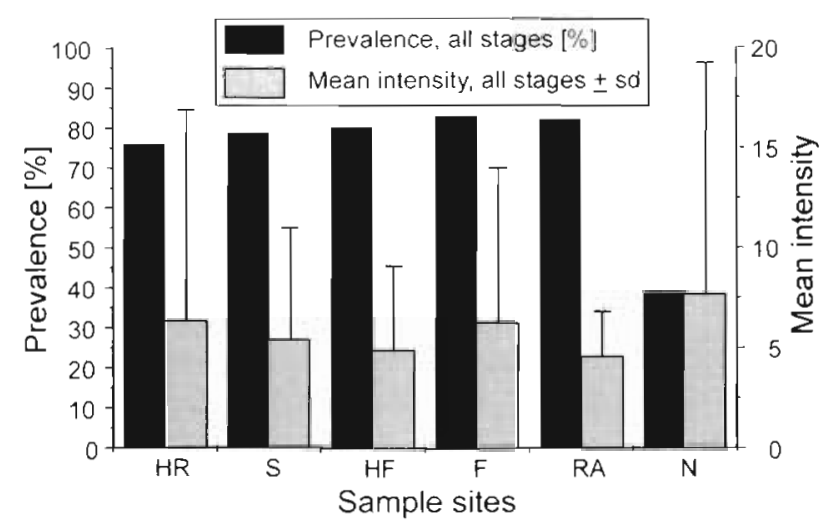

Fig. 1. Anguilla crassus. Prevalences and mean intensities (all developmental stages) in eels Anguilla anguilla over the whole sampling period at each sample site were found to be infected with $4.9 \mathrm{~A}$. crassus per eel on average. The highest prevalence here was found in summer 1994 (100\%), the lowest in autumn 1995 $(70 \%)$. At site F, 65 eels out of 78 examined were infected with $6.3 \mathrm{~A}$. crassus on average. The highest prevalence was observed in autumn 1995 (87\%), the lowest in autumn 1994 (78\%). Out of 22 eels caught at site RA, 18 were infected with $4.6 \mathrm{~A}$. crassus on average. The prevalence of $A$. crassus in eels from the river Naab with $39 \%$ was clearly lower than those from all Rhine sample sites but the mean intensity was higher in the Naab (7.7).

No significant differences between eels from different sample sites were found with regard to the alterations in swimbladder walls due to the presence of Anguillicola crassus. Table 4 shows a summary of all damage classes ranked in order of the infection status of the eels (infected with adults only, infected with larval stages only, infected with both adults and larvae, uninfected). The last column shows the damage classes found in uninfected eels in relation to all uninfected eels. Altogether $28.5 \%$ of all eels examined showed alterations in the swimbladder walls such as thickening or dilated blood vessels. Of these, $3.8 \%$ were actually not infected but showed alterations of the swimbladder wall, probably due to prior infections with $A$. crassus.

\section{DISCUSSION}

The examination of eels caught by electric fishing in the river Rhine and adjacent waters revealed a fairly high prevalence of Anguilla crassus of about $80 \%$. The mean intensity was 5.6. The prevalence in the Rhine backwater Rußheimer Altrhein was $82 \%$ and the mean intensity was 4.6. These eels were caught with fyke nets. In another study on the Rhine near Karlsruhe (Hirt 1996) almost the same prevalences and intensities were found. Eels in that study were obtained from coolant inlet grills at the Philippsburg and Karlsruhe power stations. This comparison shows that the fishing method has no influence in estimating the parasitation of eels with A. crassus.

Although zooplankton content was determined only once during the study, it is well known that copepods 
Table 3. Anguillicola crassus. Prevalences and intensities of infection in eels Anguilla anguilla from the different sample sites Prev. adult: percentage of eels infected with adult $A$. crassus; prev. larvae: percentage of eels infected with $\mathrm{L}_{3}$ and $\mathrm{L}_{4}$ larvae prev. total: percentage of eels infected with adult and/or larval $A$. crassus; intensity adult: mean number of adult $A$. crassus per infected eel; intensity larvae: mean number of larval $A$. crassus per infected eel; intensity total: mean number of adult and/or larval A. crassus per infected eel

\begin{tabular}{|c|c|c|c|c|c|c|c|}
\hline $\begin{array}{l}\text { Sampling } \\
\text { site }\end{array}$ & $\begin{array}{l}\text { No. of } \\
\text { eels }\end{array}$ & $\begin{array}{l}\text { Prev. adult } \\
\qquad(\%)\end{array}$ & $\begin{array}{c}\text { Intensity adult } \\
\bar{x} \pm \mathrm{SD}\end{array}$ & $\begin{array}{c}\text { Prev. larvae I } \\
(\%)\end{array}$ & $\begin{array}{c}\text { Intensity larvae } \\
\bar{x} \pm \mathrm{SD}\end{array}$ & $\begin{array}{l}\text { Prev. total } \\
(\%)\end{array}$ & $\begin{array}{c}\text { Intensity total } \\
\bar{x} \pm \mathrm{SD}\end{array}$ \\
\hline HR & 92 & 60 & $5.1 \pm 7.6$ & 48 & $3.6 \pm 4.7$ & 76 & $6.3 \pm 10.6$ \\
\hline S & 61 & 72 & $3.9 \pm 4.2$ & 48 & $2.9 \pm 2.9$ & 79 & $5.4 \pm 5.6$ \\
\hline $\mathrm{HF}$ & 92 & 64 & $3.4 \pm 2.5$ & 59 & $3.0 \pm 2.6$ & 80 & $4.9 \pm 4.2$ \\
\hline $\mathrm{F}$ & 78 & 72 & $4.0 \pm 5.3$ & 51 & $4.5 \pm 5.7$ & 83 & $6.3 \pm 7.7$ \\
\hline $\mathrm{RA}$ & 22 & 64 & $3.5 \pm 2.0$ & 68 & $2.2 \pm 1.2$ & 82 & $4.6 \pm 2.3$ \\
\hline$N$ & 38 & 29 & $5.6 \pm 6.0$ & 29 & $4.7 \pm 7.6$ & 39 & $7.7 \pm 11.5$ \\
\hline
\end{tabular}

are more abundant in standing waters like the Fermasee than in running waters like the Rhine due to the longer retention time. Despite different zooplankton densities at the different sample sites no significant differences in the abundance of Anguillicola crassus were found. It seems that zooplankton density does not affect the distribution of this parasite. This could be due to several factors. Eels might migrate to a large extent within the different waters but very little is known about migration of eels within their freshwater habitat (Tesch 1983). Another factor could be that the main source of infection is not the copepods as intermediate hosts but other fishes as paratenic hosts. The results of the study of Székely (1994) showed that prey fish can play a major role in the spread of $A$. crassus. In addition, the main intermediate hosts for $A$. crassus could be benthic, not planktonic, copepods, the abundance of which was not determined during this investigation. Furthermore, crayfish and other crustaceans possibly could act as intermediate or at least as paratenic hosts. Several investigations show that ostracods and gammarids can serve as intermediate hosts for A. crassus (Kennedy \& Fitch 1990, Bonneau et al. 1991, Thomas 1993, Moravec \& Konecny 1994). Hence the specificity in intermediate hosts of $A$. crassus seems to be very low within crustaceans. Additionally, Moravec (1996) shows that aquatic snails could serve as paratenic hosts for $A$. crassus. It therefore seems to be possible that crayfish Orconectes limosus, which are the main diet component of eels in the waters investigated, could play a role in transmission of $A$. crassus either as intermediate or as paratenic hosts. The same could apply for the freshwater shrimp Atyaephyra desmarestii or the mud crab Corophium curvispinum, which have built up large populations in the Rhine system (Schöll 1990, Schöll et al. 1995).

The prevalence of Anguillicola crassus in eels from the Naab was lower than those in eels from the Rhine but the mean intensities were significantly higher. This is probably be due to the fact that $A$. crassus was introduced with stocking material later in the Naab than in the Rhine and that the parasite is still spreading among these artificially created eel populations, since the Danube system is naturally free of eels (Bless et al. 1994). Ashworth (1994) suggests that mean intensity of infection stabilises after some time in the range 4 to 5 . Unfortunately it is not clear whether or not this value includes all developmental stages of $A$. crassus. This value corresponds to the results of Haenen et al (1994), who found intensities of 4.8 five years after its detection in Holland (Van Banning et al. 1985). If indeed the intensities do stabilise around 4 nematodes per infected eel, the intensities have almost reached this level in the Rhine (4.6 to 6.3 ) but not in the river Naab.

Seasonal patterns in infection of eels with Anguillicola crassus were not observed, either with larval stages or with adult nematodes. Theoretically it is

Table 4. Anguilla anguilla. Alterations of swimbladders in all examined eels

\begin{tabular}{|lccccc|}
\hline $\begin{array}{l}\text { Damage } \\
\text { class }\end{array}$ & $\begin{array}{c}\text { Adults only } \\
\text { (\% of all eels) }\end{array}$ & $\begin{array}{c}\text { Larvae only } \\
\text { (\% of all eels) }\end{array}$ & $\begin{array}{c}\text { Adults + larvae } \\
\text { (\% of all eels) }\end{array}$ & $\begin{array}{c}\text { Uninfected } \\
\text { (\% of all eels) }\end{array}$ & $\begin{array}{c}\text { Uninfected } \\
\text { (\% of uninfected eels) }\end{array}$ \\
\hline 0 & 19.0 & 10.6 & 22.0 & 20.1 & 84.1 \\
1 & 6.5 & 1.4 & 11.1 & 1.6 & 3.8 \\
2 & 0.3 & 0.5 & 3.0 & 0.8 & 5.7 \\
3 & 0.3 & 0.8 & 14.9 & 3.8 & 15.9 \\
$1-3$ & 7.0 & 2.7 & & 3.8 & \\
\hline
\end{tabular}


conceivable that in times of low water temperatures, when eels are in a quiescent period and do not feed, the number of larvae could decrease as no new infections should take place. On the other hand, the third and fourth stage larvae of $A$. crassus show retarded growth at cold temperatures (Knopf et al. in press) so they remain in the swimbladder wall longer than at higher temperatures. Other investigations are contradictory. Hartmann (1994) found increased prevalences and intensities during the summer whereas Thomas \& Ollevier (1992b) could not observe any seasonal pattern. This question should be investigated again in laboratory experiments or with larger sample surveys.

The comparison of infection intensities with Anguillicola crassus in eels of various sizes did not reveal a correlation between length, weight or condition factor of eels and intensity of infection. Other investigations with higher numbers of eels (Thomas \& Ollevier 1992b, Hartmann 1994) showed a slight correlation of length and weight with intensity of infection but not with condition factor. These, and also our results, show that A. crassus does not impact on the nutritional status of infected eels under natural conditions. However, in aquaculture $A$. crassus does lead to immense economic damage (Egusa 1979, Van Banning \& Haenen 1990).

Almost one-third (28.4\%) of all eels showed visible alterations in the swimbladder wall. These alterations were visible as inflammation of the swimbladder wall, dilated blood vessels, and cloudings or thickenings of the swimbladder wall and are due to infections with Anguillicola crassus (Van Banning \& Haenen 1990, Molnár et al. 1993). In comparison with a study of Hartmann (1994), who found $86 \%$ of the investigated eels of the river Elbe with alterations of the swimbladder, this number is relatively low This may be due to several reasons. The intensity of infection was slightly higher in eels from the river Elbe than in those from the Rhine. The method of examination might be a further reason. Hartmann (1994) used a 5-step classification; in the present study a scale with 4 steps was used. The parameters in both studies might not be exact measures and thus have a subjective component. On the other hand, the survey of Hartmann (1994) was performed a few years ago (1985 to 1991) and the situation may have improved during recent years as it did in The Netherlands (Haenen et al. 1994). In any case, the number of eels showing alterations of the swimbladder still gives reason for concern about the populations of European eels if one takes in account that malfunctioning swimbladders may lead to problems during the spawning migration (Würtz et al. 1996).

Generally, extensive surveys on the abundance and prevalence of Anguillicola crassus should be set up in Europe to monitor the development of the distribution of Anguillicola crassus, since present data have been obtained from few sample sites and rivers so far and most of these surveys were carried out over a short period of time only.

\section{LITERATURE CITED}

Ashworth ST (1994) Possible regulation in the Anguillicola crassus host-parasite system. In: Pike AW, Lewis JT (eds) Parasitic diseases. Samara Publishing Ltd, Tresaith, p 141-150

Bagenal TB, Tesch FW (1978) Age and growth. In: Bagenal T (ed) Methods for assessment of fish production in fresh waters. IBP Handbook No. 3, 3rd edn. Blackwell Scientific Publication, Oxford, p 101-136

Barus $V$ (1995) First record of Anguillicola crassus (Nematoda) in the Morava River drainage basin. Helminthologia $32: 1-2$

Barus V, Halacka K, Prokes M (1996) Presence and distribution of the nematode Anguillicola crassus in the European eel in the Morava river drainage basin, Czech Republic. Zivoc Vyroba 41(5):219-224

Belpaire C, De Charleroy D. Thomas K, Van Damme P, Ollevier $F$ (1989) Effects of eel restocking on the distribution of the swimbladder nematode Anguillicola crassus in Flanders, Belgium. J Appl Ichthyol 5:151-153

Benajiba MH, Silan P, Marques A, Bouix G (1994) Protozoan and Metazoan parasites of the eel Anguilla anguilla L., 1785. Temporal structures of their population in a Mediterranean lagoon. Ann Sci Nat Zool Biol Anim 15(4): $141-149$

Bless R, Lelek A, Waterstraat A. (1994) Rote Liste und Artenverzeichnis der in Deutschland in Binnengewässern vorkommenden Rundmäuler und Fische (Cyclostomata \& Pisces). In: Nowak E, Blab J, Bless R (eds) Rote Liste der gefährdeten Wirbeltiere in Deutschland. Schriftenr Landschaftspfl Natursch 42:137-156

Bonneau S, Blanc G, Petter A.J (1991) Etude sur la Biologie des premiers stades larvaires d'Anguillicola crassus (Nematoda, Dracunculoidea): spécificité de l'hôte intermédiaire et influence de la température sur la durée du developpement. Bull Fr Pêche Piscic 320:1-6

Canestri-Trotti G (1987) Occurrence of the nematode Anguillicola crassa Kuwahara, Niimi \& Itagaki, 1974 in eels from the Po delta, Italy. Bull Eur Assoc Fish Pathol 7(5): 109-111

De Charleroy D, Grisez L, Thomas K, Belpaire C, Ollevier F (1990) The life cycle of Anguillicola crassus. Dis Aquat Org 8:77-84

Dekker W, Van Willigen J (1989) Short note on the distribution and abundance of Anguillicola in The Netherlands. J Appl Ichthyol 1:46-47

Dupont F, Petter A (1988) Anguillicola, une épizootie plurispécifique en Europe-apparition de Anguillicola crassa (Nematoda, Anguillicolidae) chez l'anguille européenne Anguilla anguilla en Camargue, sud de la France. Bull Fr Pêche Piscic 308:38-41

Egusa S (1979) Notes on the culture of the European eel (Anguilla anguilla L.) in Japanese eel-farming ponds. Rapp P-v Reun Cons Int Explor Mer 174:51-58

El Hilali M, Yahyaoui A, Sadak A, Macchi M, Taghy Z (1996) Data on anguillicolosis observed for the first time in Morocco. Bull Fr Pèche Piscic 340:57-60

Fontaine YA, Le Belle N, Lopez E, Querat B, Vidal B, Barthelemy L, Sebert P, Alinat J, Petter AJ (1990) Infestation de populations françaises d'anguilles (Anguilla anguilla 
L.) par des nématodes (Anguillicola crassus): essais therapeutiques - évaluation de risques potentiels liés a l'écophysiologie de l'hòte. Ann Parasitol Hum Comp 6.5(2). $64-68$

Fries LT, Williams DJ, Johnson SK (1996) Occurrence of Anguillicola crassus, an exotic parasitic swimbladder nematode of eels, in the southeastern United States. Trans Am Fish Soc 125:794-797

Haenen OLM, Van Banning P (1990) Detection of larvae of Anguillicola crassus (an eel swimbladder nematode) in freshwater eels. Aquaculture 87:103-109

Haenen OLM, Van Banning P (1991) Experimental transmission of Anguillicola crassus (Nematoda, Dracunculoidea) larvae from infected prey fish to the eel Anguilla anguilla. Aquaculture 92:115-119

Haenen OLM, Van Banning P, Dekker W (1994) Infection of eel Anguilla anguilla (L.) and smelt Osmerus eperlanus (L.) with Anguillicola crassus (Nematoda, Dracunculoidea) in the Netherlands from 1986 to 1992. Aquaculture 126: 219-229

Hartmann F (1994) Untersuchungen zur Biologie, Epidemiologie und Schadwirkung von Anguillicola crassus Kuwahara, Niimi \& Itagaki 1974 (Nematoda), einem blutsaugenden Parasiten in der Schwimmblase des Europäischen Aals (Anguilla anguilla), 1st edn. Shaker Verlag, Aachen, p $1-139$

Hirt J (1996) Untersuchung des Fischanfalles im Rechengut zweier thermischer Kraftwerke am nördlichen Oberrhein. Diplomarbeit, University of Karlsruhe

Höglund J, Andersson J, Wickström H, Reizenstein M (1992) The distribution of Anguillicola in Sweden and its association with thermal discharge areas. Ir Fish Invest Ser A (Freshwater) 36:143-150

Johnson SK, Fries LT, Williams J, Huffman DG (1995) Presence of the parasitic swimbladder nematode, Anguillicola crassus, in Texas aquaculture. World Aquacult 26(3):35-36

Kennedy CR, Fitch DJ (1990) Colonization, larval survival and epidemiology of the nematode Anguillicola crassus, parasitic in the eel, Anguilla anguilla, in Britain. J Fish Biol 36: $1.17-131$

Knopf K, Würtz J, Sures B, Iaraschewski H (in press) Impact of low water temperature on the development of Anguillicola crassus in the final host Anguilla anguilla. Dis Aquat Org

Koie M (1988) Parasites in European eel Anguilla anguilla (L.) from Danish freshwater, brackish and marine localities. Ophelia 29(2):93-118

Koie M (1991) Swimbladder nematodes (Anguillicola spp.) and gill monogeneans (Pseudodactylogyrus spp.) parasitic on the European eel (Anguilla anguilla). J Cons Int Explor Mer 47:391-398

Koops H, Hartmann F (1989) Anguillicola-infestations in Germany and in German eel imports. J Appl Ichthyol 1:41-45

Lienert GA (1986) Verteilungsfreie Methoden in der Biostatistik, 3. Aufl. Verlag Anton Hain, Meisenheim

Möller H, Holst S, Lüchtenberg H, Petersen F (1991) Infection of eel Anguilla anguilla from the river Elbe estuary with two nematodes, Anguillicola crassus and Pseudoterranova decipiens. Dis Aquat Org 11:193-199

Molnár K, Baska F, Csaba G, Glávits R, Székely C (1993) Pathological and histopathological studies of the swimbladder of eels Anguilla anguilla infected with Anguilicola crassus (Nematoda: Dracunculoidea). Dis Aquat Org 15:41-50

Molnár K, Székely C (1995) Parasitological survey of some important fish species of Lake Balaton. Parasit Hung 28: $63-82$
Moravec F (1992) Spreading of the nematode Anguillicola crassus (Dracunculoidea) among the eel populations in Europe Folia Parasitol 39:247-248

Moravec F (1996) Aquatic invertebrates (snails) as new paratenic hosts of Anguillicola crassus (Nematoda: Dracunculoidea) and the role of paratenic hosts in the life cycle of this parasite. Dis Aquat Org 27:237-239

Moravec F, Konecny R (1994) Some new data on the intermediate and paratenic hosts of the nematode Anguillicola crassus Kuwahara, Nimi \& Itagaki, 1974 (Dracunculoidea), a swimbladder parasite of eels. Folia Parasitol 41. $65-70$

Moravec F, Taraschewski H (1988) Revision of the genus Anguillicola Yamaguti 1935 (Nematoda: Anguillicolidae) of the swimbladder of eels, including descriptions of two new species, A. novaezelandiae sp. n. and A. papernai sp. n. Folia Parasitol 35:125-146

Neumann W (1985) Schwimmblasenparasit Anguillicola bei Aalen. Fischer \& Teichwirt 11:322

Pazooki J, Székely C (1994) Survey of the paratenic hosts of Anguillicola crassus in Lake Velence, Hungary. Acta Vet Hung 42(1):87-97

Petter J, Cassone J, Le Belle N (1990) Observations sur la biologie des premiers stades larvaires d'Anguillicola crassus, nématode parasite d'anguille. Ann Parasitol Hum Comp $65(1): 28-31$

Pilcher MW, Moore JF (1993) Distribution and prevalence of Anguillicola crassus in eels from the tidal Thames catchment. J Fish Biol 43:339-344

Reimer L, Hildebrand A, Scharberth D, Walter U (1994) Anguillicola crassus in the Baltic sea: field data supporting transmission in brackish waters. Dis Aquat Org 18:77-79

Sachs L (1992) Angewandte Statistik, 7. Aufl. Springer Verlag, Berlin

Schöll F (1990) Zur Bestandssituation von Corophium curvispinum (Sars) in Rheingebiet. Lauterbornia 5:67-70

Schöll F, Becker C, Tittizer T (1995) Das Makrozoobenthos des schiffbaren Rheins von Basel bis Emmerich 1986-1995. Lauterbornia 21:115-137

Spangenberg R, Reinhold H (1992) Fundbericht zum Anguillicola-Befall von Aalen in den ostdeutschen Bundesländern. J Appl Ichthyol 8:323

Székely C (1994) Paratenic hosts for the parasitic nematode Anguillicola crassus in Lake Balaton, Hungary. Dis Aquat Org 18:11-20

Székely C (1995) Dynamics of Anguillicola crassus (Nematoda: Dracunculoidea) larval infection in paratenic host fishes of lake Balaton, Hungary. Acta Vet Hung 43(4): $401-422$

Székely C (1996) Experimental studies on the infectivity of Anguillicola crassus third stage larvae (Nematoda) from paratenic hosts. Folia Parasitol 43:305-311

Székely C, Làng M, Csaba G (1991) First occurrence of Anguillicola crassus in Hungary. Bull Eur Assoc Fish Pathol $11(4): 162$

Székely C, Pazooki J, Molnár K (1996) Host reaction in paratenic fish hosts against $3 r d$ stage larvae of Anguillicola crassus. Dis Aquat Org 26:173-180

Taraschewski H, Moravec F, Lamah T, Anders K (1987) Distribution and morphology of two helminths recently introduced into European eel populations: Anguillicola crassus (Nematoda, Dracunculoidea) and Paratenuisentis ambiguus (Acanthocephala, Tenuisentidae). Dis Aquat Org 3:167-176

Tesch FW (1983) Der Aal. Biologie und Fischerei. Paul Parey, Hamburg

Thomas K (1993) The life cycle of the eel parasite Anguillicola crassus. Dissertation, University of Leuven 
Thomas K, Ollevier F (1992a) Paratenic hosts of the swimbladder nematode Anguillicola crassus. Dis Aquat Org 13: $165-174$

Thomas K, Ollevier F (1992b) Population biology of Anguillicola crassus in the final host Anguilla anguilla. Dis Aquat Org 14:163-170

Van Banning P, Haenen OLM (1990) Effect of the swimbladder nematode Anguillicola crassus in wild and farmed eel, Anguilla anguilla. In: Perkins FO, Cheng TC (eds)

Editorial responsibility: Wölfgang Körting,

Hannover, Germany
Pathology in marine science. Academic Press, New York, p $317-330$

Van Banning P, Heermans W, Van Willigen JA (1985) Anguillicola crassa, een nieuwe aalparasiet in de Nederlandse wateren. Visserij 38:237-240

Würtz J, Taraschewskı H, Pelster B (1996) Changes in gas composition in the swimbladder of the European eel (Anguilla anguilla) infected with Anguillicola crassus (Nematoda). Parasitology 112:233-238

Submitted: July 30, 1997; Accepted: November 20, 1997 Proofs received from author(s): February 20, 1998 